\title{
NUTRIENT LOSSES BY WATER EROSION
}

\author{
Ildegardis Bertol $^{1 *}$; Eloy Lemos Mello ${ }^{1}$; Jean Cláudio Guadagnin ${ }^{1}$; Almir Luis Vedana Zaparolli; \\ Marcos Roberto Carrafa ${ }^{3}$ \\ ${ }_{2}^{l}$ UDESC/CAV - Depto. de Solos, C.P. 281 - 88520-000 - Lages, SC - Brasil. \\ ${ }^{2}$ Colégio Agrícola Caetano Costa, C.P. 15 - 88570-000 - São José do Cerrito, SC - Brasil. \\ *Corresponding author <a2ib@cav.udesc.br>
}

\begin{abstract}
Water erosion causes soil degradation, which is closely related to nutrient losses either in, the soluble form or adsorbed to soil particles, depending mainly on the adopted soil management system. This study was carried out in São José do Cerrito, SC, Brazil, between March 2000 and June 2001. The objective was to quantify available nitrogen, phosphorus, potassium, calcium and magnesium losses in water erosion obtained with simulated rainfall in the following soil management systems: conventional tillage with no-crop (bare soil) (BS), conventional tillage with soybean (CT), reduced tillage with soybean (RT), no tillage with soybean on a desiccated and burned natural pasture (DBNP), and no tillage with soybean on a desiccated natural pasture (DNP). A rotating boom rainfall simulator was used to perform three rainfall tests with constant intensity of $64 \mathrm{~mm} \mathrm{~h}^{-1}$ and sufficient duration to reach constant runoff rate, on a clayey-loam, well-structured Typic Hapludox, with an average slope of $0.18 \mathrm{~m} \mathrm{~m}^{-1}$. The first test was carried out five days before soybean emergence and the second and third at 30 and 60 days, respectively. The nutrient concentration in water and total losses of nitrogen, phosphorus, potassium, calcium and magnesium were higher under $\mathrm{CT}$ than in the other soil management systems.
\end{abstract}

Key words: nutrient concentration, water loss, simulated rainfall

\section{PERDAS DE NUTRIENTES NA ÁGUA DA EROSÃo HÍDRICA}

\begin{abstract}
RESUMO: A erosão hídrica causa o empobrecimento dos solos, devido ao transporte de nutrientes, os quais são transportados tanto adsorvidos aos colóides do solo quanto solubilizados na água, podendo variar com o sistema de manejo solo. O trabalho foi conduzido em São José do Cerrito (SC), entre março de 2000 e junho de 2001, com o objetivo de quantificar as perdas de nitrogênio, fósforo, potássio, cálcio e magnésio na água da erosão hídrica sob chuva simulada, nos seguintes sistemas de manejo: aração+duas gradagens sem cultivo do solo (SSC), aração+duas gradagens com cultivo de soja (PCO), escarificação+uma gradagem com cultivo de soja (CMI), semeadura direta de soja em campo natural dessecado e queimado (SDDQ) e semeadura direta de soja em campo natural dessecado (SDD). Utilizando um simulador de chuvas de braços rotativos, foram aplicados três testes de chuva, com intensidade constante de $64 \mathrm{~mm} \mathrm{~h}^{-1}$ e com durações suficientes para a enxurrada atingir taxa constante, sobre um Nitossolo Háplico alumínico, com $0,18 \mathrm{~m} \mathrm{~m}^{-1}$ de declividade média. $\mathrm{O} 1^{\circ}$ teste foi aplicado cinco dias após a semeadura da soja, e o $2^{\circ}$ e $3^{\circ}, 30$ e 60 dias após o primeiro, respectivamente. A concentração e a perda total de nitrogênio, fósforo, potássio, cálcio e magnésio na água da erosão hídrica foram maiores no PCO do que nos demais sistemas de manejo do solo.
\end{abstract}

Palavras-chave: concentração de nutrientes, perda de água, chuva simulada

\section{INTRODUCTION}

The loss of nutrients by water erosion in crop fields contributes to soil degradation, especially under conventional tillage (Bertol, 1994; Schick et al., 2000). $\mathrm{N}$ and $\mathrm{P}$ are the main nutrients that restore soil fertility, and together with $\mathrm{Ca}, \mathrm{Mg}, \mathrm{K}$ and organic matter, are subject to losses by water erosion (Bertol \& Miquelluti, 1993; Schick et al., 2000; Mello, 2002).

Nutrient losses can be expressed as concentration in the water or in the sediment and as amounts lost (Schick, 1999; Schick et al., 2000). These losses are affected by soil type, cover and fertility; slope of the ter- rain; amount, method and time of fertilizers application; intensity, amount and moment of occurrence of rainfall (Gascho et al., 1998); as well as by soil management practices (Barisas et al., 1978; Schick et al., 2000; Mello, 2002).

Soil conservation tillage are characterized by the presence of more extensive ground cover and/or surface roughness than under conventional tillage. Therefore, soil and water losses are reduced, which could decrease nutrient losses by erosion under conservation tillage (King et al., 1996; Seganfredo et al., 1997; Schick et al., 2000). The concentrations of nutrients in water resulting from water erosion are, in general, similar or greater under 
cpnservation tillage than under conventional tillage (Barisas et al., 1978; Schick et al., 2000), what can be explained by the reduction of the total sediment load in the outflow, with the consequent relative increase of the colloidal sediment load in the storm runoff under conservation tillage. It could also result from the use of soil tillage to incorporate fertilizers under these soil management systems (Gascho et al., 1998).

Nutrient losses are expected to be reduced in soil management systems that preserve plant residues. However, even under such conditions plant residues can be washed off (Burwell et al., 1975), becoming sources of soluble nutrients (Barisas et al., 1978; Johnson et al., 1979), which can be lost by water erosion.

Nutrient gain rates are usually inversely proportional to soil and water losses. As erosion decreases, an increase in the proportion of smaller particles is observed in the eroded material (Alberts \& Moldenhauer, 1981), resulting in an increase of the proportion of mineral and organic colloids, and consequently the sediment becomes richer in nutrients (Freitas \& Castro, 1983; Schick et al., 2000). $\mathrm{Ca}$ and $\mathrm{Mg}$ losses by water erosion are usually high (Bertol, 1994; Schick et al., 2000). This occurs because these elements are strongly adsorbed by colloids in the soil, which makes it easy for them to be transported with the sediment, and also because they occur in high concentrations in erosion water. The objective of this work was to quantify losses of $\mathrm{P}, \mathrm{K}, \mathrm{Ca}, \mathrm{Mg}$ and $\mathrm{N}$ in water erosion, during soybean cultivation, in different soil management systems, using simulated rain.

\section{MATERIAL AND METHODS}

The study was developed on an Typic Hapludox, clayey textured, located in São José do Cerrito, SC, Brazil, at $27^{\circ} 39^{\prime} 47^{\prime \prime} \mathrm{S}$ and $50^{\circ} 34^{\prime} 48^{\prime \prime} \mathrm{W}$, between March 2000 and June 2001. The mean slope of the experimental area was $0.18 \mathrm{~m} \mathrm{~m}^{-1}$; Table 1 presents data on soil depth, granulometry and organic carbon content.

The experimental area was initially covered by natural pasture, improved in March 1999 with the introduction of ryegrass (Lollium multiflorum) and red clover (Trifolium pratense) and the surface application of $3 \mathrm{tha}^{-1}$

Table 1 - Horizon depths and granulometric composition of the soil profile.

\begin{tabular}{lccccc}
\hline Horizon & Thickness & Clay & Sand & Silt & OC \\
\hline & $\mathrm{cm}$ & $-\ldots-\ldots-1$ & \\
A1 & $0-16$ & 627 & 118 & 255 & 13.5 \\
A2 & $16-32$ & 733 & 102 & 165 & 7.6 \\
AB & $32-50$ & 680 & 105 & 215 & 5.8 \\
BA & $50-68$ & 706 & 113 & 181 & 3.7 \\
B & $68-115^{+}$ & 592 & 115 & 293 & 2.9 \\
\hline
\end{tabular}

OC: organic carbon. dolomitic lime. In May 2000, the area that received the treatments corresponding to bare soil, conventional tillage and reduced tillage, was tilled with one plowing and two harrowing operations. The other part, which received treatments corresponding to reduced tillage and conventional tillage, was corrected with $11 \mathrm{t} \mathrm{ha}^{-1}$ dolomitic lime and $230 \mathrm{~kg} \mathrm{ha}^{-1}$ triple superphosphate, in addition to 70 $\mathrm{kg} \mathrm{ha}^{-1}$ potassium chloride, which were incorporated to the soil with one harrowing operation. Plowing was performed with a disk plow, transversally to the slope, at a depth of approximately $0.20 \mathrm{~m}$. Harrowings were carried out with a leveling disk harrow, also transversally to the slope, at a depth of approximately $0.15 \mathrm{~m}$. The rest of the area, where treatments of no tillage on a desiccated natural pasture and of no tillage on a desiccated and burned natural pasture were installed, was not tilled nor received liming or fertilization at that time.

Black oat (Avena strigosa) was sown as a cover crop in May 2000, without fertilization, in the area where the reduced tillage and conventional tillage treatments were installed. In September 2000, during the oat bloom, the crop was chemically desiccated; yield was $5.4 \mathrm{t} \mathrm{ha}^{-1}$ dry mass. The natural pasture was desiccated on the same date; yield was $1.4 \mathrm{t} \mathrm{ha}^{-1}$ dry mass.

In November 2000 the following soil management treatments $(n=2)$ were installed over the oat and natural pasture dry mass residues: one plowing+two harrowings and no-cropping (bare soil) (standard Universal Soil Loss Equation plot - USLE) - BS; one plowing+two harrowings (conventional tillage) on the desiccated oat residue, with soybean - CT; one scarification+one harrowing (reduced tillage) on the desiccated oat residue, with soybean - RT; direct soybean sowing on the residue of the desiccated natural pasture DNP; and, direct soybean sowing on the desiccated and burned natural pasture (no residue) - DBNP.

For treatments BS, CT and RT, tillage was performed parallel to the slope, five days before sowing soybean. Plowing was performed with a disk plow at a depth of approximately $0.20 \mathrm{~m}$; harrowing was performed with a leveling harrow at a depth of approximately $0.15 \mathrm{~m}$. Scarification was performed at a $0.20 \mathrm{~m}$ depth; the scarifier shanks were adjusted to a distance of $0.50 \mathrm{~m}$ between them. The soybean was sown with a punch-planter, in rows 0.50 $\mathrm{m}$ apart from each other. Desiccation of the natural pasture for treatments DNP and DBNP was performed five days before the application of the first simulated rainfall test. For treatment DBNP, the field was burned immediately before the application of the first simulated rainfall test.

Soybean fertilization was made with $80 \mathrm{~kg} \mathrm{ha}^{-1}$ $\mathrm{KCl}$ and $100 \mathrm{~kg} \mathrm{ha}^{-1}$ triple superphosphate, incorporated by one harrowing parallel to the slope, for CT and RT, at sowing time. For treatments DNP and DBNP, fertilizers were applied on the soil surface, at soybean sowing time, without incorporation. 
Three simulated rainfall tests were applied. The first test was performed five days after the soybean was sown and the others 30 and 60 days after the first, with a constant intensity of $64 \mathrm{~mm} \mathrm{~h}^{-1}$ and variable duration, sufficient for the runoff to reach a steady rate.

Experimental units consisted of tem, $3.5 \times 11 \mathrm{~m}$ plots, installed according to Embrapa (1975). The simulated rainfalls were applied with a rotating boom rainfall simulator (Swanson, 1975). The simulator covered simultaneously two plots, which were replicates of the soil management treatments.

Runoff sampling was performed by collecting samples inside $300 \mathrm{~mL}$ glass jars, according to the methodology described by Cogo (1981). Four jars were utilized per plot; two were collected when the runoff started to flow and two were collected when it reached a constant rate (those moments were variable for each treatment). In the laboratory, 3 to 5 droplets of hydrochloric acid $(2.5 \mathrm{~N})$ were added to each runoff jar, in order to flocculate and precipitate the soil particles in suspension, as recommended by Cogo (1981). After the solid particles were precipitated, an aliquot of approximately $10 \mathrm{~mL}$ of sediment-free water was taken from each sample (jar), which was utilized to determine the soluble contents of $\mathrm{P}, \mathrm{K}, \mathrm{Ca}, \mathrm{Mg}$ and $\mathrm{N}$ in the water, using the methodologies described by Tedesco et al. (1995). Data were interpreted by analysis of variance and compared by Duncan test $(P=0.05)$.

\section{RESULTS AND DISCUSSION}

\section{Concentration of nutrients in the erosion water}

The mean $\mathrm{N}$ concentration of the runoff water for the conventional tillage (CT) was approximately, $2.3 ; 3.0 ; 4.7$; and 8.8 times greater than for bare soil (BS), reduced tillage (RT), desiccated and burned natural pasture (DBNP) and desiccated natural pasture (DNP), respectively, for the simulated rainfall tests (Table 2). In the case of BS, this can be explained by the absence of fertilization, while for DNP and DBNP, the differences can be probably attributed to the low $\mathrm{N}$ mineralization rate during that period and, for DBNP specifically, to plant mass burning in the natural pasture.

Table 2 - Concentrations of soluble N, P, K, Ca and Mg in water erosion, under different management systems of the soil and simulated rainfalls applied (means of two replicates).

\begin{tabular}{|c|c|c|c|c|c|}
\hline Rainfall & BS & RT & $\mathrm{CT}$ & DBNP & DNP \\
\hline & \multicolumn{5}{|c|}{ Nitrogen $\left(\mathrm{mg} \mathrm{dm}^{-3}\right)$} \\
\hline Test 1 & $3.36 \mathrm{Ba}$ & $3.50 \mathrm{Ba}$ & $6.30 \mathrm{Aa}$ & $1.86 \mathrm{Ca}$ & $0.70 \mathrm{Da}$ \\
\hline Test 2 & $2.24 \mathrm{Ab}$ & $0.90 \mathrm{Cb}$ & $1.11 \mathrm{Bb}$ & $0.73 \mathrm{Db}$ & $0.56 \mathrm{~Eb}$ \\
\hline Test 3 & $0.76 \mathrm{Dc}$ & $0.43 \mathrm{Cc}$ & $7.11 \mathrm{Ac}$ & $1.11 \mathrm{Bc}$ & $0.39 \mathrm{Cc}$ \\
\hline \multirow[t]{2}{*}{ Mean } & $2.12 \mathrm{~B}$ & $1.61 \mathrm{C}$ & $4.84 \mathrm{~A}$ & $1.04 \mathrm{D}$ & $0.55 \mathrm{E}$ \\
\hline & \multicolumn{5}{|c|}{ Phosphorus (mg dm${ }^{-3}$ ) } \\
\hline Test 1 & $0.01 \mathrm{Ca}$ & $0.01 \mathrm{Ca}$ & $0.01 \mathrm{Ca}$ & $1.88 \mathrm{Ba}$ & $2.19 \mathrm{Aa}$ \\
\hline Test 2 & $0.01 \mathrm{Aa}$ & $0.01 \mathrm{Aa}$ & $0.01 \mathrm{Aa}$ & $0.01 \mathrm{Ab}$ & $0.01 \mathrm{Ab}$ \\
\hline Test 3 & $0.01 \mathrm{Aa}$ & $0.01 \mathrm{Aa}$ & $0.01 \mathrm{Aa}$ & $0.01 \mathrm{Ab}$ & $0.01 \mathrm{Ab}$ \\
\hline \multirow[t]{2}{*}{ Mean } & $0.01 \mathrm{C}$ & $0.01 \mathrm{C}$ & $0.01 \mathrm{C}$ & $0.64 \mathrm{~A}$ & $0.74 \mathrm{~B}$ \\
\hline & \multicolumn{5}{|c|}{ Potassium $\left(\mathrm{mg} \mathrm{dm}^{-3}\right)$} \\
\hline Test 1 & $3.88 \mathrm{Ea}$ & $29.58 \mathrm{Ba}$ & $34.60 \mathrm{Aa}$ & $21.60 \mathrm{Ca}$ & $16.68 \mathrm{Da}$ \\
\hline Test 2 & $2.73 \mathrm{Db}$ & $7.78 \mathrm{Ab}$ & $7.60 \mathrm{Ab}$ & $5.68 \mathrm{Cb}$ & $6.13 \mathrm{Bb}$ \\
\hline Test 3 & $3.88 \mathrm{Ea}$ & $6.60 \mathrm{Bc}$ & $7.18 \mathrm{Ab}$ & $5.63 \mathrm{Cb}$ & $4.15 \mathrm{Dc}$ \\
\hline \multirow[t]{2}{*}{ Mean } & $3.50 \mathrm{E}$ & $14.65 \mathrm{~B}$ & $16.45 \mathrm{~A}$ & $10.97 \mathrm{C}$ & $9.00 \mathrm{D}$ \\
\hline & \multicolumn{5}{|c|}{ Calcium (mmolc $\mathrm{kg}^{-1}$ ) } \\
\hline Test 1 & $05.4 \mathrm{Ca}$ & $134.2 \mathrm{Aa}$ & $140.4 \mathrm{Aa}$ & $21.0 \mathrm{Ba}$ & $21.3 \mathrm{Ba}$ \\
\hline Test 2 & $15.9 \mathrm{Cb}$ & $78.8 \mathrm{Ab}$ & $77.5 \mathrm{Ab}$ & $27.5 \mathrm{Ba}$ & $28.8 \mathrm{Ba}$ \\
\hline Test 3 & $25.4 \mathrm{Ec}$ & $103.3 \mathrm{Ac}$ & $85.4 \mathrm{Bb}$ & $58.4 \mathrm{Db}$ & $68.4 \mathrm{Cb}$ \\
\hline \multirow[t]{2}{*}{ Mean } & $15.6 \mathrm{C}$ & $105.4 \mathrm{~A}$ & $101.1 \mathrm{~A}$ & $35.6 \mathrm{~B}$ & $39.5 \mathrm{~B}$ \\
\hline & \multicolumn{5}{|c|}{ Magnesium (mmolc $\left.\mathrm{kg}^{-1}\right)$} \\
\hline Test 1 & $26.5 \mathrm{Da}$ & $172.4 \mathrm{Ba}$ & $193.7 \mathrm{Aa}$ & $51.5 \mathrm{Ba}$ & $58.3 \mathrm{Ca}$ \\
\hline Test 2 & $21.9 \mathrm{Cb}$ & $83.0 \mathrm{Ab}$ & $84.5 \mathrm{Ab}$ & $33.1 \mathrm{Bb}$ & $31.3 \mathrm{Bb}$ \\
\hline Test 3 & $25.5 \mathrm{Da}$ & $82.1 \mathrm{Ab}$ & $68.7 \mathrm{Bc}$ & $46.5 \mathrm{Cc}$ & $49.0 \mathrm{Cc}$ \\
\hline Mean & $24.6 \mathrm{C}$ & $112.5 \mathrm{~A}$ & $115.6 \mathrm{~A}$ & $43.7 \mathrm{~B}$ & $46.2 \mathrm{~B}$ \\
\hline
\end{tabular}

BS: bare soil; RT: reduced tillage; CT: conventional tillage; DBNP: no tillage in desiccated and burned field; DNP: no tillage in desiccated field. Upper case letters in rows compare means between treatments; lower case letters in columns compare means between rainfall tests, by Duncan test at $5 \%$. 
For RT, which received the same fertilization as $\mathrm{CT}$, the smaller concentration of $\mathrm{N}$ relative to $\mathrm{CT}$ partially disagrees with the reports of Barisas et al. (1978) and Johnson et al. (1979). The total incorporation of the cropping residue into the soil for $\mathrm{CT}$, probably with greater decomposition, must have contributed to the greater concentration and release of $\mathrm{N}$ in that treatment. For all treatments, $\mathrm{N}$ concentrations were higher for rainfall test 1 than for tests 2 and 3, probably because of the greater soil organic matter mineralization and release of $\mathrm{N}$ in the initial stage of the experiment, which probably tended to decrease in the following stages.

The concentrations of $\mathrm{P}$ in the water were low in all treatments and rainfall sessions applied (Table 2), in agreement with other reports (Barisas et al., 1978; McIsaac et al., 1995; Schick et al., 2000), what can be explained by the low concentrations of this element in the soil and by its strong adsorption by colloids. DNP had the highest $\mathrm{P}$ concentration in water, followed by DBNP, in the means of applied rainfall tests, which is explained by the high concentrations of this element occurring in the first rainfall test. This probably occurred because, in these treatments, fertilization was performed by broadcasting fertilizer on the soil surface, allowing greater contact of the element with the runoff water, increasing its concentration in the erosion water, as verified by Gascho et al. (1998). Therefore, in the first applied rainfall, most of the soluble $\mathrm{P}$ on the soil surface was probably lost in the water erosion. On the other hand, phosphorus that had been applied to tillage treatments was incorporated to the soil, decreasing its contact with the runoff and consequently reducing its loss in the water erosion.

The highest concentration of $\mathrm{K}$ was found in $\mathrm{CT}$ water erosion (Table 2), with respect to the mean of the applied rainfall tests, because $\mathrm{K}$ is a relatively mobile element in the soil and when incorporated, as it is the case in CT, it behaves in a similar way in relation to its runoff concentration. The lowest $\mathrm{K}$ concentration, for the rainfall test means, occurred in BS, because of the absence of fertilization and plant residues in the soil. For $\mathrm{CT}$, the concentration of $\mathrm{K}$ was 50 and $83 \%$ higher than in DBNP and DNP, respectively, for the rainfall test means. For the DNP treatment, the stubble in the desiccated field served as a source of nutrients, which were probably mineralized and made available for runoff transportation, as verified by Barisas et al. (1978) and Johnson et al. (1979). For DBNP, the same phenomenon probably occurred, with faster mineralization, since burning the desiccated field in this treatment accelerated the decomposition of organic compounds, making the soluble nutrients available for runoff transportation.

Treatments that received fertilization (RT, CT, DBNP and DNP - Table 2) had mean K concentrations fourfold greater in the runoff water of the first rainfall as compared to the other applied rainfalls, in agreement with Pote et al. (1996) and Gascho et al. (1998), thus demonstrating the importance of a correct surface runoff management, especially for the first rain that falls after the application of fertilizers to the soil, or after surface plant residue management operations have been carried out, as it is the case with soil conservation tillage. This behavior is explained by the high solubility of $\mathrm{K}$, which can be easily lost through water erosion.

The $\mathrm{Ca}$ and $\mathrm{Mg}$ concentrations were higher for RT and CT than for the other treatments, in relation to the mean of the applied simulated rain tests (Table 2), and attributed to the application of dolomitic lime in these treatments. For the no-tillage treatments (DBNP and DNP), the concentrations of these elements in the water erosion were smaller because these treatments only received $1 / 3$ of the lime rate relative to the rate applied for RT and CT, which was applied about a year before. On the other hand, the smallest concentrations of $\mathrm{Ca}$ and $\mathrm{Mg}$ were verified in $\mathrm{BS}$, resulting from the complete absence of liming in this treatment. For treatments RT, CT, DBNP and DNP, concentrations of $\mathrm{Ca}$ and $\mathrm{Mg}$ were higher for the first rainfall test than for the others, except for DBNP and DNP. Schick et al. (2000) and Mello (2002) emphasize the importance of controlling the runoff that occurs for open rain, especially when it is intense or large in volume. It is also important to take into account the moment of the rainfall occurrence in relation to the moment of lime application, with regard to the importance of runoff control.

\section{Water total volume lost by erosion}

Water losses caused by water erosion were relatively high in all treatments and simulated rainfalls applied (Table 3), with relatively small differences between treatments, as also verified by other authors (Cogo, 1981; Bertol, 1995; Bertol et al., 1997b). RT was the most effective treatment, with water loss equivalent to $25 \%$ of the applied rainfall, while the less effective was BS, which lost the equivalent to $42 \%$ of the rainfall.

This demonstrates that support conservation practices, such as terracing, capable of storing water in the

Table 3 - Total water volume lost in erosion, under different management systems of the soil and simulated rainfalls applied (means of two replicates).

\begin{tabular}{|c|c|c|c|c|}
\hline Treatment & Test 1 & Test 2 & Test 3 & Mean \\
\hline & \multicolumn{4}{|c|}{ - $\%$ of applied rainfall } \\
\hline BS & 40 & 44 & 43 & 42 \\
\hline RT & 25 & 23 & 27 & 25 \\
\hline $\mathrm{CT}$ & 35 & 40 & 40 & 38 \\
\hline DBNP & 13 & 37 & 34 & 28 \\
\hline DNP & 14 & 39 & 38 & 30 \\
\hline
\end{tabular}

BS: bare soil; RT: reduced tillage; CT: conventional tillage; DBNP: no tillage in desiccated and burned field; DNP: no tillage in desiccated field. 
cropping field, must be adopted, avoiding nutrient losses by water erosion. The total losses of nutrients by water erosion are directly related, among other factors, to the concentration of nutrients in the water and to the volume of water lost by erosion (Alberts et al., 1978; Schick et al., 2000; Mello, 2002).

\section{Total nutrient losses in water erosion}

Losses of $\mathrm{N}$ in water erosion were $2.6 ; 3.5 ; 6.2$; and 10.4 times greater for the CT treatment than for BS, RT, DBNP and DNP, respectively (Table 4), and are proportional to the concentration of this element in the water (Table 2) and to water loss (Table 3). The smaller loss of $\mathrm{N}$ in RT, relative to $\mathrm{CT}$, can be attributed to the combined effect of low concentration of the element in the runoff (Table 2) with smaller water loss (Table 3 ). In treatments CT, BS, DNP and DBNP, on the other hand, the differences in water loss were small and, therefore, $\mathrm{N}$ losses were more influenced by the concentrations of this element in the runoff water than by water losses.

RT was the most effective treatment in reducing P losses (Table 4), mainly because of the smaller water loss (Table 3). BS and CT did not differ between themselves with regard to $\mathrm{P}$ losses, which can be explained both by water losses (Table 3 ) and by the concentrations of this element in the water (Table 2). The highest total $P$ loss occurred for the DNP treatment, followed by DBNP, which presented values, on average 43 times greater than the mean for the other treatments. For these two treatments, the total losses of $\mathrm{P}$ were strongly influenced by the losses that occurred in the first rainfall test, similarly to what was observed for concentration (Table 2), because of the surface application of phosphate fertilizer in both treatments, as verified by Pote et al. (1996) and Gascho et al. (1998) and, in the case of the DBNP treatment, also because of the effect of plant residue burning.

$\mathrm{K}$ losses were relatively high, regardless of the management system (Table 4), in agreement with Schick et al. (2000). This occurred because $\mathrm{K}$ is naturally found in relatively high concentrations in the soil and also because it is highly soluble in water. $\mathrm{K}$ loss of the CT treatment was 1.4 time greater than for RT, considering the total rainfall applied (Table 4); this difference was strongly influenced by the difference in water loss (Table 3 ), with smaller influence of the concentration of this element in the water (Table 2); this fact was also verified by Schick et al. (2000). In relation to rainfall, K losses followed the same behavior observed for its concentra-

Table 4 - Losses of soluble N, P, K, Ca and Mg in erosion water, under different management systems of the Typic Hapludox and simulated rainfalls applied (means of two replicates).

\begin{tabular}{|c|c|c|c|c|c|}
\hline Rainfall & $\mathrm{BS}$ & RT & $\mathrm{CT}$ & DBNP & DNP \\
\hline \multicolumn{6}{|c|}{ Nitrogen $\left(\mathrm{kg} \mathrm{ha}^{-1}\right)$} \\
\hline Test 1 & $0.52 \mathrm{Ca}$ & $0.97 \mathrm{Ba}$ & $2.01 \mathrm{Aa}$ & $0.17 \mathrm{Da}$ & $0.13 \mathrm{Da}$ \\
\hline Test 2 & $0.85 \mathrm{Bb}$ & $1.90 \mathrm{Ab}$ & $0.33 \mathrm{Cb}$ & $0.24 \mathrm{CDb}$ & $0.18 \mathrm{Db}$ \\
\hline Test 3 & $0.28 \mathrm{Cc}$ & $0.90 \mathrm{Ba}$ & $2.03 \mathrm{Aa}$ & $0.29 \mathrm{Cc}$ & $0.11 \mathrm{Da}$ \\
\hline Total & $1.65 \mathrm{~B}$ & $1.25 \mathrm{C}$ & $4.37 \mathrm{~A}$ & $0.70 \mathrm{D}$ & $0.42 \mathrm{E}$ \\
\hline \multicolumn{6}{|c|}{ Phosphorus $\left(\mathrm{g} \mathrm{ha}^{-1}\right)$} \\
\hline Test 1 & $1.56 \mathrm{Ca}$ & $2.75 \mathrm{Ca}$ & $3.15 \mathrm{Ca}$ & $273.59 \mathrm{Ba}$ & $413.29 \mathrm{Aa}$ \\
\hline Test 2 & $3.72 \mathrm{Ab}$ & $2.09 \mathrm{Db}$ & $3.05 \mathrm{Ca}$ & $3.27 \mathrm{Bb}$ & $3.26 \mathrm{Bb}$ \\
\hline Test 3 & $3.63 \mathrm{Ab}$ & $2.09 \mathrm{Db}$ & $2.45 \mathrm{Cb}$ & $2.99 \mathrm{Bb}$ & $2.99 \mathrm{Bb}$ \\
\hline Total & $8.91 \mathrm{C}$ & $6.93 \mathrm{D}$ & $8.65 \mathrm{C}$ & $279.85 \mathrm{~B}$ & $419.54 \mathrm{~A}$ \\
\hline \multicolumn{6}{|c|}{ Potassium $\left(\mathrm{kg} \mathrm{ha}^{-1}\right)$} \\
\hline Test 1 & $0.61 \mathrm{Da}$ & $8.08 \mathrm{Ba}$ & $11.05 \mathrm{Aa}$ & $3.15 \mathrm{Ca}$ & $3.15 \mathrm{Ca}$ \\
\hline Test 2 & $1.00 \mathrm{Db}$ & $1.62 \mathrm{Cb}$ & $2.30 \mathrm{Ab}$ & $1.85 \mathrm{Bb}$ & $1.98 \mathrm{Bb}$ \\
\hline Test 3 & $1.40 \mathrm{Bc}$ & $1.38 \mathrm{Bc}$ & $1.82 \mathrm{Ac}$ & $1.69 \mathrm{Ab}$ & $1.28 \mathrm{Bc}$ \\
\hline Total & $3.01 \mathrm{E}$ & $11.08 \mathrm{~B}$ & $15.17 \mathrm{~A}$ & $6.69 \mathrm{C}$ & $6.41 \mathrm{D}$ \\
\hline \multicolumn{6}{|c|}{ Calcium $\left(\mathrm{kg} \mathrm{ha}^{-1}\right)$} \\
\hline Test 1 & $17 \mathrm{Ea}$ & $738 \mathrm{Ba}$ & $890 \mathrm{Aa}$ & $62 \mathrm{Da}$ & $80 \mathrm{Ca}$ \\
\hline Test 2 & $115 \mathrm{Db}$ & $330 \mathrm{Bc}$ & $472 \mathrm{Ab}$ & $179 \mathrm{Cb}$ & $184 \mathrm{Cb}$ \\
\hline Test 3 & $189 \mathrm{Dc}$ & $432 \mathrm{Ab}$ & $433 \mathrm{Ac}$ & $343 \mathrm{Cc}$ & $410 \mathrm{Bc}$ \\
\hline Total & $321 \mathrm{E}$ & $1500 \mathrm{~B}$ & $1795 \mathrm{~A}$ & $584 \mathrm{D}$ & $674 \mathrm{C}$ \\
\hline \multicolumn{6}{|c|}{ Magnesium $\left(\mathrm{kg} \mathrm{ha}^{-1}\right)$} \\
\hline Test 1 & $50 \mathrm{Ea}$ & $570 \mathrm{Ba}$ & $742 \mathrm{Aa}$ & $93 \mathrm{Da}$ & $132 \mathrm{Ca}$ \\
\hline Test 2 & $97 \mathrm{Db}$ & $209 \mathrm{Bb}$ & $309 \mathrm{Ab}$ & $130 \mathrm{Cb}$ & $120 \mathrm{Cb}$ \\
\hline Test 3 & $107 \mathrm{Dc}$ & $206 \mathrm{Ab}$ & $202 \mathrm{Ac}$ & $163 \mathrm{Cc}$ & $176 \mathrm{Bc}$ \\
\hline Total & $254 \mathrm{E}$ & $985 \mathrm{~B}$ & $1253 \mathrm{~A}$ & $386 \mathrm{D}$ & $428 \mathrm{C}$ \\
\hline
\end{tabular}

BS: bare soil; RT: reduced tillage; CT: conventional tillage; DBNP: no tillage in desiccated and burned field; DNP: no tillage in desiccated field. Upper case letters in rows compare means between treatments; lower case letters in columns compare means between rainfall tests, by Duncan test at $5 \%$. 
tion in the water erosion, i.e., the greatest losses in treatments that received fertilization occurred in the first simulated rainfall applied, and the lower losses were recorded in the subsequent rainfalls, due to the high solubility of this element, which easily causes loss by water erosion.

$\mathrm{Ca}$ and $\mathrm{Mg}$ losses by water erosion were high (Table 4), which is in agreement with the work of Schick et al. (2000), explained by the fact that these elements are relatively soluble in water and because they can be found in high concentrations in the soil, which received dolomitic lime. CT was the less effective treatment in controlling losses of these elements. With regard to RT, for example, this can be explained especially by the differences in water loss between the two treatments (Table 3), since the concentrations of those elements in the water were equal under these soil management systems (Table 3 ). $\mathrm{Ca}$ and $\mathrm{Mg}$ losses were greater in the first applied rainfall than in the others, according to the behavior observed for the concentration of these elements in water erosion (Table 2).

$\mathrm{K}, \mathrm{Ca}$ and $\mathrm{Mg}$ losses were smaller for treatments BS, DNP and DBNP than for RT and CT (Table 4). This occurred because of the absence of fertilization and liming in BS and, in the case of DNP and DBNP, because these treatments received only $1 / 3$ of the lime that to RT and $\mathrm{CT}$ received.

Nutrient losses were in general influenced by the concentrations of elements in the water, and especially by water losses. This demonstrates that support conservation practices that reduce water losses in cropping fields must be adopted, such as terracing, even when the crops are managed under soil conservation tillage, as recommended by Bertol (1995) and Bertol et al. (1997a; 2000).

\section{CONCLUSION}

The concentrations of $\mathrm{N}, \mathrm{P}, \mathrm{K}, \mathrm{Ca}$ and $\mathrm{Mg}$ in the water lost by erosion are strongly influenced by the soil management system adopted and increase with increasing fertilization and soil tillage intensity. Highest concentrations of $\mathrm{N}, \mathrm{P}, \mathrm{K}, \mathrm{Ca}$ and $\mathrm{Mg}$ in the water lost by erosion occur under conventional tillage and, in the case of $\mathrm{P}$, under no tillage in natural fields.

\section{REFERENCES}

ALBERTS, E.E.; MOLDENHAUER, W.C. Nitrogen and phosphorus transported by eroded soil aggregates. Soil Science Society of America Journal, v.45, p.391-396, 1981.

ALBERTS, E.E.; SCHUMAN, G.E.; BURWELL, R.E. Seasonal runoff losses of nitrogen and phosphorus form Missouri Valley loss watersheds. Journal of Environmental Quality, v.7, p.203-207, 1978.

BARISAS, S.G.; BAKER, J.L.; JOHNSON, H.P.; LAFLEN, J.M. Effect of tillage systems on runoff losses of nutrients, a rainfall simulation study. Transactions of the American Society of Agricultural Engineering, v.21, p.893-897, 1978.

BERTOL, I. Perdas de nutrientes por erosão hídrica em diferentes sistemas de manejo de solo sob rotação de culturas. Universidade \& Desenvolvimento, v.2, p.174-184, 1994.
BERTOL, I. Comprimento crítico de declive para preparos conservacionistas de solo. Porto Alegre: UFRGS, 1995. 185p. (Tese -Doutorado)

BERTOL, I.; MIQUELLUTI, D.J. Perdas de solo, água e nutrientes reduzidas pela cultura do milho. Pesquisa Agropecuária Brasileira, v.28, p.1.205$1.213,1993$.

BERTOL, I.; COGO, N.P.; CASSOL, E.A. Distância entre terraços usando o comprimento crítico de rampa em dois preparos conservacionistas de solo. Revista Brasileira de Ciência do Solo, v.24, p.417-425, 2000.

BERTOL, I.; COGO, N.P.; LEVIEN, R. Comprimento crítico de declive em sistemas de preparos conservacionistas de solo. Revista Brasileira de Ciência do Solo, v.21, p.139-148, 1997a.

BERTOL, I.; COGO, N.P.; LEVIEN, R. Erosão hídrica em diferentes preparos do solo logo após as colheitas de milho e trigo, na presença e ausência dos resíduos culturais. Revista Brasileira de Ciência do Solo, v.21, p.409-418, 1997b.

BURWELL, R.E.; TIMMONS, D.R.; HOLT, R.F. Nutrient transport in surface runoff as influenced by soil cover and seasonal periods. Soil Science Society of America Proceedings, v.39, p.523-528, 1975

COGO, N.P. Effect of residue cover, tillage induced roughness, and slope length on erosion and related parameters. West Lafayette: Purdue University, 1981. 346p. (Thesis - Doctor)

EMPRESA BRASILEIRA DE PESQUISAAGROPECUÁRIA - EMBRAPA. Recomendações gerais do encontro sobre uso do simulador de chuva em pesquisa de conservação do solo no Brasil. In: ENCONTRO NACIONAL SOBRE PESQUISA DE EROSÃO COM SIMULADORES DE CHUVA, Londrina, 1975. Resumos. Londrina: EMBRAPA, 1975. p.107-120.

FREITAS, P.L.; CASTRO, A.F. Estimativas das perdas de solo e nutrientes por erosão no Estado do Paraná. Boletim Informativo, SBCS, v.8, p.43$52,1983$.

GASCHO, G.J.; WAUCHOPE, R.D.; DAVIS, J.G.; TRUMAN, C.C.; DOWLER, C.C.; HOOK, J.E.; SUMNER, H.R.; JOHNSON, A.W. Nitrate-nitrogen, soluble, and bioavailable phosphorus runoff from simulated rainfall after fertilizer application. Soil Science Society of America Journal, v.62, p.1.711-1.718, 1998.

JOHNSON, A.H.; BAKER, J.L.; SHRADER, W.D.; LAFLEN, J.M. Tillage system effect on sediment and nutrients in runoff from small watersheds. Transactions of the American Society of Agricultural Engineering, v.22, p.1.110-1.114, 1979 .

KING, K.W.; RICHARDSON, C.W.; WILLIANS, J.R. Simulation of sediment and nitrate loss on a vertissol with conservation practices. Transactions of the American Society of American Engineering, v.39, p.2.139-2.145, 1996.

MCISAAC, G.F.; MITCHELL, J.K.; HIRSCHI, M.C. Dissolved phosphorus concentrations in runoff from simulated rainfall on corn and soybean tillage systems. Journal of Soil and Water Conservation, v.50, p.383-387, 1995.

MELLO, E.L. Erosão hídrica em diferentes sistemas de manejo do solo sob chuva simulada. Lages: UDESC/CCA, 2002. 88p. (Dissertação Mestrado)

POTE, D.H.; DANIEL, T.C.; SHARPLEY, A.M.; MOORE JR., P.A.; EDWARDS, D.R.; NICHOLS, D.J. Relating extractable soil phosphorus to phosphorus losses in runoff. Soil Science Society of America Journal, v.60, p.855-859, 1996.

SCHICK, J. Erosão hídrica em Cambissolo Húmico álico submetido a diferentes sistemas de manejo e cultivo do solo. Lages: UDESC/CCA, 1999. 114p. (Dissertação - Mestrado)

SCHICK, J.; BERTOL, I.; BALBINOT JR., A.A.; BATISTELA, O. Erosão hídrica em Cambissolo Húmico alumínico submetido a diferentes sistemas de preparo e cultivo do solo: II. perdas de nutrientes e carbono orgânico. Revista Brasileira de Ciência do Solo, v.24, p.437-447, 2000.

SEGANFREDO, M.L.; ELTZ, F.LF.; BRUM, A.C.R. Perdas de solo, água e nutrientes por erosão em sistemas de culturas em plantio direto. Revista Brasileira de Ciência do Solo, v.21, p.287-291, 1997.

SWANSON, N.P. Suggestions for use rotating-boom field plot rainfall simulator to obtein data for application of the soil loss equation. Entre-Rios: FAO, 1975. 65p. (Report of FAO Consultant)

TEDESCO, M.J.; GIANELLO, C.; BISSANI, C.A.; BOHNEN, H.; VOLKWEISS, S.J. Análise de solos, plantas e outros materiais. 2.ed. Porto Alegre: UFRGS, 1995. 174p.

Received August 18, 2002

Accepted April 16, 2003 